\title{
MACQUARIE ISLAND FLORA AND FAUNA MANAGEMENT- INTERPRETING PROGRESS AND PREDICTIONS FOR THE FUTURE
}

\author{
by N.P. Brothers and G.R. Copson
}

(with three tables and two text-figures)

BROTHERS, N.P. \& COPSON, G.R., 1988 (viii): Macquarie Island flora and fauna management --

interpreting progress and predictions for the future. Pap. Proc. R. Soc. Tasm., 122(1): 129-135.

https://doi.org/10.26749/rstpp.122.1.129 Papers presented at the Macquarie Island Symposium, Hobart, May 1987. ISSN 0080-4703. National Parks and Wildlife Service, Magnet Couri, Sanciy Bay, Tasmania, Australia 7005 .

The flora and fauna of Macquarie Island, in the subantarctic, have been experiencing a gradual but sure deterioration since the introduction of alien species. The greatest single achievement in attempts to stop this has been success with controlling the European rabbit (Oryctolagus cuniculus). The actual impact of rabbit control on other introduced species causing ecological damage has far exceeded expectations. Plant communities diminished by 100 years of rabbit grazing are re-establishing rapidly. Because of the success with controlling rabbit numbers, total elimination of feral cats (Felis catus) and wekas (Gallirallus australis) can be achieved, with the major potential benefit being the recovery of some seabird populations which are all but extinct on the main island. However, unless the effort given to these and other management problems discussed can be maintained until completion, the progress made will be rapidly lost and greater ecological problems could result.

Key Words: flora and fauna management, rabbit control, feral cats, wekas, Macquarie Island.

\section{INTRODUCTION}

Macquarie Island, in the subantarctic, is a Nature Reserve under the Tasmanian National Parks and Wildlife Act 1970. The reserve provides a first-class example of an island with native flora and fauna that have been severely affected by the thoughtless introduction of alien species, a problem common to many subantarctic islands (Jenkin et al. 1981, Clark \& Dingwall 1985). Some of the changes resulting from these introductions have been in progress for 150 years, potentially sufficient time for any influences to have stabilised. With present attitudes favouring the reversal of changes caused by such introductions, an important consideration must be whether intervention is warranted and what it will achieve. The consequences of intervention are not always certain but fortunately the right course to rectify ecological damage on Macquarie Island was taken. In 1919, a major turning point in conservation on Macquarie Island came about, when 110 years of intensive commercial exploitation of seals and penguins for their oil or fur was terminated (Cumpston 1968). From this time on, the island has been recognised as worthy of protection from disturbance by man (Mawson 1922), this protection being legally declared since 1933 (Anon 1987).
All current management problems and attempts to solve them are closely linked to the introduction of the European rabbit (Oryctolagus (uniculus), which has been recognised as having caused the greatest modifications to Macquarie Island's ecology. The Tasmanian National Parks and Wildlife Service (TNPWS) involvement in Macquarie Island management commenced in 1972, at which time rabbits were already considered detrimental to the island (Taylor 1955, Costin \& Moore 1960). Determining the extent of damage, and attempting to predict the effects of rabbit control on native flora and fauna, before control was initiated, were priorities for the following six years.

This work substantiated earlier observations of researchers that steps would have to be taken to ensure survival and recovery of certain native flora and fauna on Macquarie Island. Hence, in 1978, TNPWS moved into the second phase of pest species control and associated monitoring of resulting changes. With this, the effort to document the ecology of species, other than rabbits, considered relevant to management problems proved invaluable not only for planning control programmes but for assessing progress. This work is continuing at present. 


\section{RESEARCH AND MANAGEMENT PROGRESS}

\section{Rabbits}

First introduced in the 1870 's as food for sealers (Cumpston 1968), rabbits became established over the whole of Macquarie Island in varying densities, dependent upon habitat, with a weather-induced lluctuating population of between 50000 and 150000 (Copson et al. 1981). Although the decision to control rabbit numbers was taken in the mid-1960's, it was then based on general observations of destruction to vegetation and soils.

$D$ ata to prove that control of rabbits was warrant ed were gathered in an intensive programme between 1972 and 1978. While this work was underway, progress continued with establishing the European rabbit flea (Spilopsyllus cuniculi) (Skira et al. 1983), the vector necessary for the disease, myxomatosis, that had been determined, in 1968, as the only suitable method of controlling rabbits on Macquarie Island (G.C. Johnston, unpublished report). By 1978, investigations had determined that rabbit control was necessary and, as rabbit fleas had finally become sufficiently established, myxoma virus was introduced (Brothers el al. 1982). Since this first introduction of myxomatosis, a campaign of virus introduction has continued over the whole island each austral spring and summer, with the effects being monitored at standard count areas (table 1). By 1986 rabbit numbers had been reduced by about $80 \%$ to approximately 15000 , most of this being achieved in the first three to four years. Caroline Cove and Hurd Point count area figures (table 1) demonst rate the slow progress in rabbit control experienced in some areas, due to low flea abundance, but consistently low counts for four or more years at most other count areas ind icate the ability to keep rabbit numbers at a reduced level.

To have arrived, in 1986, at a point where rabbit numbers had been reduced to an environmentally acceptable level, with still further potential for reduction, was a major achievement, given the difficulties encountered with the work. Because of unfavourable weather conditions and the ecology of Macquarie Island rabbits, it took ten years and the release of 241600 fleas (Skira et al. 1983) before these were well enough established to proceed with control using myxomatosis. Fleas from wild rabbits are still being transferred to pockets of rabbits where fleas are absent.

Problems in inoculating rabbits with myxoma virus had to be overcome. Initially, live trapping was used to obtain rabbits, averaging two animals per man day. The redevelopment of a "dart gun" (Brothers 1982) increased the inoculation rate to an average of 30 rabbits per man day. Using this technique of inoculation permits indefinite control over the whole island with minimal effort.

The long-term viability of myxoma virus for rabbit control on Macquarie Island is dependent on a number of factors. Indications are that all the

TABLE 1

Rabbit Numbers at Standard Count Areas on Macquarie Island, 1974-86*

Count area

Mean number of rabbits

\begin{tabular}{lrrrrrrrrrrr} 
& $\mathbf{1 9 7 4}$ & $\mathbf{1 9 7 5}$ & $\mathbf{1 9 7 6}$ & $\mathbf{1 9 7 8}$ & $\mathbf{1 9 7 9}$ & $\mathbf{1 9 8 0}$ & $\mathbf{1 9 8 1}$ & $\mathbf{1 9 8 3}$ & $\mathbf{1 9 8 4}$ & $\mathbf{1 9 8 5}$ & $\mathbf{1 9 8 6}$ \\
\hline NW Square Lake & 2.9 & 6.0 & 10.4 & 15.7 & 5.1 & 0 & 1.0 & 0.7 & 0.7 & 0 & 4.0 \\
S Square Lake & 16.4 & 36.5 & 39.6 & 66.4 & 8.9 & 16.4 & 26.0 & 4.7 & 16.9 & 0.6 & 12.0 \\
Red River & 29.3 & 44.4 & 43.6 & 81.4 & 17.1 & 6.0 & 9.0 & 0.6 & 2.6 & 2.9 & 0.6 \\
Prion Lake & 15.0 & 14.7 & 18.0 & 35.4 & 40.8 & 41.3 & 42.0 & 4.8 & 6.4 & 1.0 & 2.6 \\
Green Gorge I & 23.0 & 19.0 & 29.0 & 33.1 & 25.3 & 23.5 & 9.5 & 0.8 & 0.8 & 3.3 & 1.0 \\
Green Gorge II & 15.3 & 18.4 & 26.6 & 34.0 & 35.2 & 33.5 & 15.0 & 1.0 & 1.5 & 2.0 & 0 \\
Cormorant Point & & 9.6 & 14.9 & 68.4 & 8.5 & 0.7 & 0 & 0.6 & 2.5 & & 5.0 \\
Aurora Point & & 12.4 & 15.1 & 56.2 & 50.9 & 40.3 & 1.5 & 5.0 & 4.0 & & \\
Caroline Creek & 8.0 & 10.9 & 22.0 & 20.0 & 13.0 & 25.0 & & 17.0 & 17.6 & 26.2 & 7.9 \\
Hurd Point & 13.3 & 15.3 & 16.5 & 8.0 & 13.0 & & & 10.0 & 21.2 & 20.0 & 9.1 \\
Yearly mean of all counts & 15.4 & 18.7 & 23.6 & 41.9 & 21.8 & 20.7 & 13.0 & 4.5 & 7.4 & 7.0 & 4.7 \\
\hline
\end{tabular}

* Ten two-hectare count areas were monitored. Counts were usually made monthly in most years from 1974 to 1986 (myxoma virus introduced in 1978) and are continuing. (Brothers et al. 1982.) 
TABLE 2

\section{Comparison of Flea Infestation in Rabbits on Macquarie Island Before and After* Introduction of Myxoma Virus in 1978}

\begin{tabular}{|c|c|c|c|c|c|c|c|c|c|}
\hline \multirow{2}{*}{$\begin{array}{l}\text { Sampling } \\
\text { period }\end{array}$} & \multirow{2}{*}{$\begin{array}{c}\text { Number of } \\
\text { rabbiss } \\
\text { sampled }\end{array}$} & \multicolumn{6}{|c|}{ Flea abundance } & \multicolumn{2}{|l|}{ Totals } \\
\hline & & $1-A$ & $\%$ & $5=20$ & $\%$ & $>20$ & $\%$ & $\begin{array}{c}\text { Pabbits with } \\
\text { neas }\end{array}$ & $\%$ \\
\hline $\begin{array}{l}\text { Before myxoma } \\
\text { virus }\end{array}$ & $5 ! 41$ & 762 & 15 & 818 & 16 & 415 & 8 & 1995 & 39 \\
\hline $\begin{array}{l}\text { After myxoma } \\
\text { virus }\end{array}$ & 981 & 400 & 41 & 229 & 23 & 111 & 11 & 740 & 75 \\
\hline
\end{tabular}

* Sampie period $1985-86$.

factors discussed in Brothers el al. (1982) are favourable. It was uncertain whether fleas would persist in the rabbit population following epizootics, and the presence of fleas is critical for effective control of rabbits on Macquarie Island with myxomatosis. Table 2 compares flea abundance in the rabbit population before and after myxomatosis, and a significant increase in flea abundance is apparent.

\section{Feral Cats}

The presence of feral domestic cats (Felis catus) since about 1820 on Macquarie Island (Debenham 1945) has caused a considerable reduction in populations of indigenous fauna (Taylor 1979, Brothers 1984). The Australian Antaretic Division initiated a study of feral cats on the island in 1974 (Jones 1977) and studies were continued by TNPWS (Brothers et al. 1985). The conclusions of these studies were that up to 500 cats occur scattered over the whole island, mostly in herbfield or tussock grassland. Seasonal food availability controls the size of the population, there being a great dependence on rabbits since burrow-nesting petrels were preyed upon to such an extent that species diversity and abundance are now low.

In the ten years since 1976 , a total of 522 cats has been destroyed by live trapping, shooting and gassing in burrows. Serious efforts to eradicate cats did not commence until 1985, although the decision to proceed with eradication was made by TNPWS in 1983, when rabbit control was having a noticeable impact on cat abundance due to food shortages that it created. It is not possible, at this stage, to assess the impact of eradication measures, as interpreting data is complicated by the use of varying techniques and effort expended on eradication. No obvious alteration is apparent in such aspects as age structure of the cat population (fig. 1) that may have been brought about by a high proportion of the population being removed. The percentage of cats sampled has remained the same with respect to coat colour, but the sex ratio of these cats now favours females, which may be an early indication of progress with population reduction (table 3). There is no doubt, however, that the effort required in 1980 to kill 112 cats was subtantially less than that expended in 1985 and 1986 for a similar result. Trapping, shooting and gassing of cats in an effort to achieve eradication is continuing.

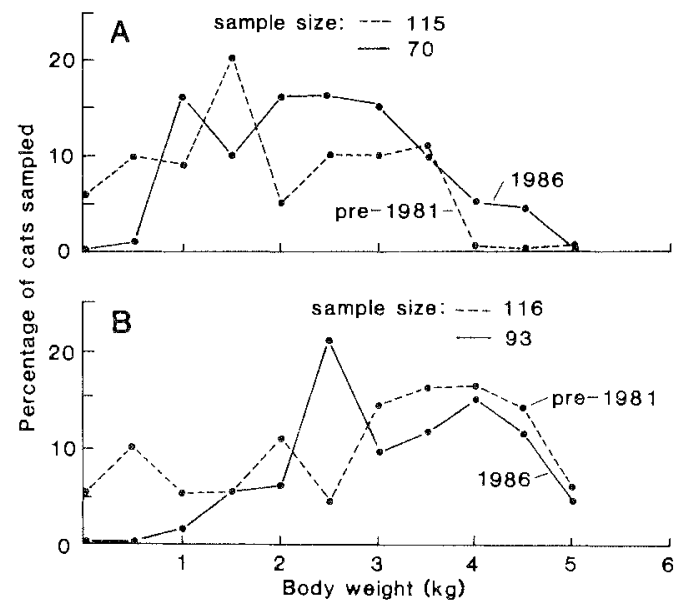

FIG. I-Comparison between pre-1981 (---) and 1986 ( ) percentages of $(A)$ female and $(B)$ male cats sampled on Macquarie Island, in body weight intervals of $500 \mathrm{~g}$. 
TABLE 3

Sex Ratio and Coat Colour of Feral Cats Sampled on Macquarie Island

\begin{tabular}{|c|c|c|c|c|c|c|}
\hline \multirow[t]{2}{*}{ Year } & \multicolumn{2}{|c|}{ Sample size } & \multirow[t]{2}{*}{ Sex ratio } & \multicolumn{3}{|c|}{ Coat colour } \\
\hline & $\mathbf{F}$ & $\mathbf{M}$ & & Ginger & Tabby & Black \\
\hline Before 1981 & 109 & 137 & M 1:0.8 & $26 \%$ & $74 \%$ & $2 \%$ \\
\hline 1984 & 31 & 41 & M 1:0.8 & $19 \%$ & $82 \%$ & $1.9 \%$ \\
\hline 1986 & 70 & 57 & $F \quad 1: 0.8$ & $27 \%$ & $71 \%$ & $1.4 \%$ \\
\hline
\end{tabular}

\section{Wekas}

The weka (Gallirallus australis), introduced to Macquarie Island in the 1870 's from Stewart Island (Cumpston 1968), is thought to have played a major role in the destruction of burrow-nesting petrel populations (Brothers 1984) and in the extinction of two endemic birds (Taylor 1979). In recent times the impact of wekas on petrels has not been great, because they are largely confined to coastal tussock grassland where few petrels now remain (Brothers 1984, Brothers \& Skira 1984). The necessity to eradicate wekas became apparent in 1978 but, prior to embarking on a programme of intensive eradication in 1985, aspects of their ecology were studied during 1979 (Brothers \& Skira 1984). As early as 1980 , there were obvious signs that the island's population of about 500 wekas had decreased significantly. In 1976 the total number of weka sightings was 326 and in 1979 it was 232 ( 98 of which were shot). Only 11 were seen in 1984, and 22 of 23 seen in 1986 were either trapped or shot. This rapid decrease in the weka population is thought to be largely due to increased cat predation as their chief food source, rabbits, were reduced in numbers by myxomatosis. At present, wekas are rarely seen anywhere except at the northern tip of the island. All animals encountered are being shot or trapped and eradication of this pest is imminent.

\section{Vegetation}

Although the extent to which rabbits influence erosion patterns on the island has yet to be clearly defined, there is good documentation with regard to their influence on vegetation. Throughout the whole period of the TNPWS involvement with management of Macquarie Island, studies of the vegetation have been carried out, with emphasis on long-term monitoring of changes due to the presence or, more recently, absence of rabbits. Copson (1984) summarised the relationship between rabbits and the vascular flora. Of the 45 species of vascular plants now recorded from the island (Seppelt el al. 1984), only 41 were identified prior to rabbit control; seven of the 41 species were never grazed by rabbits, two species suffered badly and 19 species benefited by the presence of rabbits. Of the 21 species listed as rare, 12 were grazed by rabbits and two of these were adversely affected (Copson 1984).

It is estimated that about $50 \%$ of present herbfield will revert to tussock grassland (fig. 2), in response to the severe reduction in rabbit numbers. This will bring about dramatic changes in the distribution and abundance of many species of plants. Species such as the tussock grass Poa foliosa and the herb Stilbocarpa polaris will thrive, to the detriment of most of the 19 species that have benefited by the presence of rabbits. These changes are already, in the eight years since myxomatosis was introduced, very evident and are being monitored regularly at a number of permanent study sites.

\section{General}

Preventing any further introductions of potentially serious pest species to the island is an area of management that is of great concern. Informal arrangements with the Australian Antarctic Division over quarantine are being developed and implemented at present.

Some species have received attention in ongoing studies because they are considered vulnerable. Wandering albatrosses (Diomedia exulans), black-browed albatrosses (D. melanophris) and grey-headed albatrosses ( $D$. chrysostoma) are all rare (Tomkins 1985, Copson, this volume). Subantarctic fur seals (Arctocephalus gazella) and antarctic fur seals (A. tropicalis) are breeding in very low numbers on Macquarie lsland (Shaughnessy et al., this volume) and these populations are being closely monitored. Brothers (1984) identified burrow-nesting petrels that are rare and 
vulnerable. Because of the status of all these species, TNPWS does not permit any research on them that may cause disturbance, particularly to breeding success. Protection from research causing intervention $n$ is also extended to some rare plants on the island.

In addition to controlling disturbance by scientists, measures have also been taken to reduce the effects of other visitors. A handbook has been prepared to provide general guidelines to intending visitors (Anon 1987). Relocating walking tracks to avoid areas more sensitive to disturbance is an ongoing ac tivity. In some habitats, a footprint may remain visible for 20 years or more. Recently it was decided by TNPWS that it would be necessary to close a section of the island to human access for part of the year, to reduce disturbance to the few wandering albatrosses that remain. This action can be applied to other species and/or historical locations, if it is considered necessary.

\section{MANAGEMENT REQUIREMENTS AND PREDICTIONS FOR THE FUTURE}

A major problem with interpreting management progress and monitoring population trends of species on Macquarie Island has been the absence of adequate comparative information on earlier population sizes and distributions. Survey work to establish distribution and numbers is often not given priority, the tendency being to step straight into much narrower fields of research. Apart from studies of species with specific management requirements already discussed, there have been recent attempts to define population sizes and distribution of other species on the island, for example, king penguins (Aptenodytes patagonicus) (Rounsevell \& Copson 1982), king shags (Phalacocorax albiventer purpurascens) (Brothers 1985), gentoo penguins (Pygoscelis papua) (Robertson 1986), royal penguins (Eudyptes schlegeli) (Copson \& Rounsevell 1987). These studies will provide essential baseline information for management, for which re-assessment of these populations in the future will also be required.

If present management objectives of feral cat and weka eradication and maintained control of rabbits are achieved, recolonisation and expansion of burrow-nesting petrels, along with a return of natural plant communities, are likely to occur. Several interesting interactions of other species with these changes are predicted, some of which may be to a certain extent detrimental. Ship rats

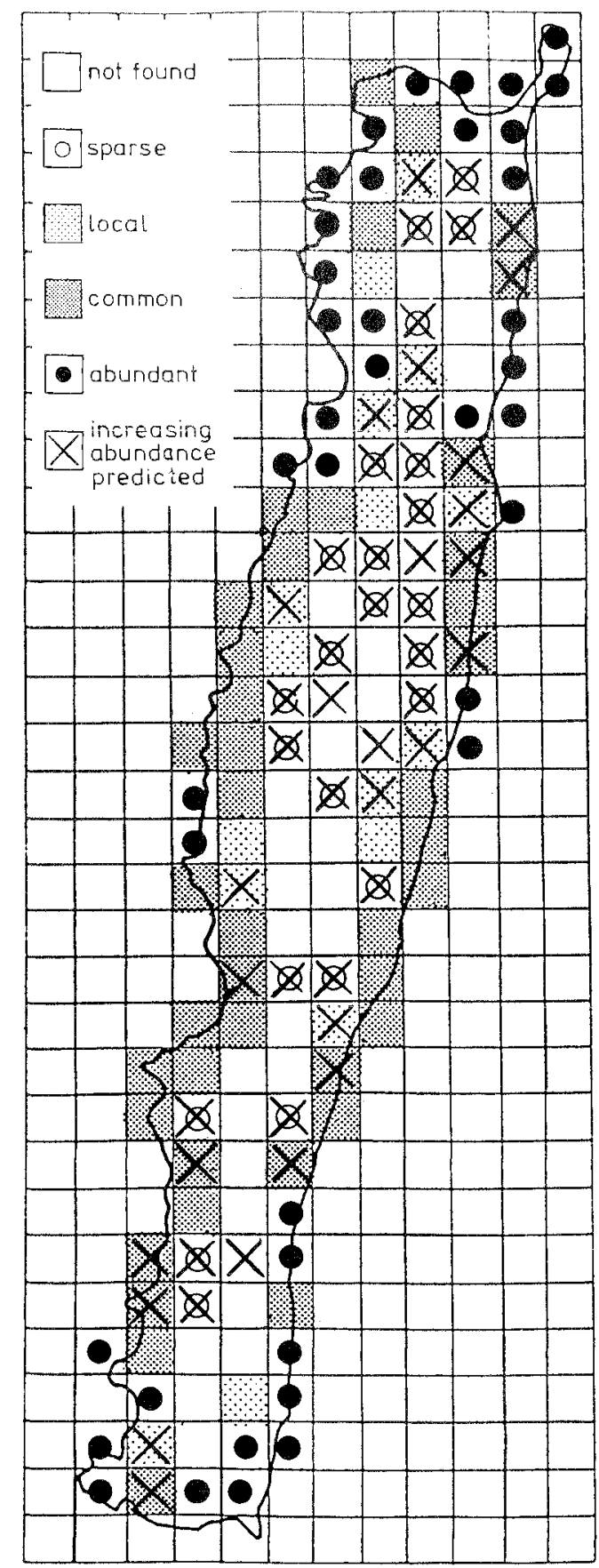

FIG. 2 - Distribution of the tussock grass Poa foliosa on Macquarie Island (Copson 1984). 
(Ratus rattus), introduced to the island late in the last cen tury (Cumpston 1968), are associated only with the lussock grassland (G.R. Copson, unpublished data). In response to the spread of tussock grassland, they will have access to large areas where they are unable to exist at present. In his study of the rats "diet in 1978, Copson (1986) did not substantiate the observation of Brothers (1984) that rats eat burrowing petrels, beeause, at present, rat predation on petrels is localised, very seasonal, and therefore difficult to detect. The impact of rats on burrowing petrels may be substantial in the future, as they will have access to smaller species of petrels, through expansion of tussock grassland into existing petrel colonies and recolonisation from offshore stacks of species formerly widespread in tussock grassland (Brothers 1984). Provided recolonisation and expansion of petrel populations can be accelerated byeradication of their main predators, cats and wekas, these populations should be able to withstand rat predation in the long term.

There has already been a noticeable change in the breeding distribution of the great skuas (Stercorarius skua lonnbergi) in response to rabbit control (Skira 1984). The abundance of rabbits for food enabled skuas to breed over a wide area of the island and their predation on petrels was high because of this. With rabbits in short supply, skuas have been forced to concentrate nesting territories closer to other food sources, such as penguin colonies. Their predation on burrowing petrels has therefore decreased and will presumably decrease further as regrowth of tussock grassland affords greater protection to the petrels.

Eradication of cats and wekas must be achieved rapidly before tussock grassland and burrowing petrels recolonise substantially. Cats will keep wek numbers in check for as long as the rabbit population is controlled. But, once burrowing petrel populations increase, so too will cats and wekas, and predation by these, coupled with that of rats, may have an even greater impact on petrel populations than any seen on the island so far.

Financial constraints on, and priority allocation of TNPWS work constantly threaten the continuation of the work on Macquarie Island. To abandon the present wildlife managment programmes will mean that 15.5 man years, representing approximately $50000 \mathrm{~km}$ of walking to carry out field programmes, will have been all but wasted, given the above predictions. Present efforts must be sustained or intensified, until eradication of cats and wekas is achieved. The need to maintain indefinite control of rabbit numbers, so their impact on flora is kept at an acceptably low level, must also be recognised. This control will require comparatively little effort and, if the opportunity arises through new techniques, eradication of rabbits may become possible in the future.

A management plan for Macquarie Island Nature Reserve is essential for proper long-term protection. However, unless serious consideration is given to extending some form of protection to the waters around the island, protection of the island itself may be of little long-term value, since all indigenous vertebrates on the island are totally reliant for their survival on marine food resources, which they are now having to share ever increasingly with humans.

\section{ACKNOWLEDGEMENTS}

During 13 years, indispensible logistic support from the Antarctic Division, Commonwealth Government Department of Science and Technology, and the involvement of members of Australian National Antarctic Research Expeditions have contributed tremendously to the success of Macquarie Island flora and fauna management efforts. John Cooper's contribution as referee of this paper is also appreciated.

\section{REFERENCES}

ANON, 1987: MACOUARIE ISLAND NATURERESERVE: VISITOR'S HANDBOOK. National Parks and Wildlife Service, $48 \mathrm{p}$.

BROTHERS, N.P., 1982: A simple and efficient method of administering myxoma virus. In WARNER, H.K., FARRER, K.T.H. \& WHITTON, W.I. (Eds): Innovations in Australian Technology 1980-81,6:20. Australian Academy of Technical Science.

BROTHERS N.P., 1984: Breeding, distribution and status of burrow-nesting petrels at Macquarie Island. Aust. Wildl. Res., 11: 113 131.

BROTHERS, N.P., 1985: Breeding biology, diet and morphometrics of the King Shag, Phalacrocorax alhiventer purpurascens, at Macquarie Island. Aust. Wildl. Res., 12: 81-94.

BROTHERS, N.P., EBERHARD, I.E., COPSON, G.R \& SKIRA, I.J., 1982: Control of rabbits on Macquarie Island by myxomatosis. Aust. Wildl. Res., 9: 477.485.

BROTHERS, N.P. \& SKIRA, I.J., 1984: The Weka on Macquarie Island. Notornis, 31: 145-154.

BROTHERS, N.P., SKIRA, I.J. \& COPSON, G.R., 1985: Biology of the Feral Cat, Felis carus (L.), on Macquarie Island. Aust. Wildl. Res., 12: $425-436$. 
CIARK, M.R. \& DINGWALL, P.R., 1985: CONSER YATION OFISLANDSIN THESOUTHERN OCLAN: A REVWEW OF THE PROTECTED AREAS OF INSULANTARCTICA. IUCN

COPSON, G.R., 1984: An annotated atlas of the vascular flora of Macquarie Island. ANARE Res. Notess, is.

COPSON, G.R., 1986: The diet of the introduced rodents Mus musculus L. and Ratius ratus L on subantarctic Macquarie Island. Aust. Wildt. Res., 13: 441445

COPSON, G.R., 1988: The status of the black-browed and grey-headed albatrosses on Macquarie Island. Pap. Proc. R. Soc. Tasm., 122(1): 137141.

COPSON, G.R., BROTHERS, N.P. \& SKIRA, I.J., 1981: Distribution and abundance of the rabbit, Orvetolagus cuniculus (L.) at subantarctic Macquaric Island. Aust. Wildl. Res., 8: 597-611.

COPSON, G.R. \& ROUNSEVELL, D.E., 1987: The abundance of Royal Penguins (Eudyples schlegeli, Finsch) breeding at Macquarie Island. ANARE Res. Notes, 41.

COSTIN, A.B. \& MOORE, D.M., 1960: The effects of rabbit grazing on the grasslands of Macquarie Island. J. Ecol., 48: 729-732.

CUMPSTON, J.S., 1968: Macquarie Island. ANARE Sci. Rep., Ser. A(1).

DEBENHAM, F. (Ed.), 1945: THE VOYAGE OF CAPTAIN BELLINGHAUSEN TO THE ANTARCTIC SEAS, 1819-1921. Transprinted by Hakluyt Society.

JENKIN, J.F., JOHNSTONE, G.W. \& COPSON, G.R. 1981: Introduced animal and plant species on Macquarie Island. Colloque sur les Ecosystemes Subantarctique, Paimont, 1981. CNFRA, 51: 301313 .
JONF.S, E., 1977: Ecology of the feral cat, Felis calus (L.). (Carnivora: Felidae), on Macquarie Island. Aust. Wildl. Res., 4: 249-262.

MAWSON, D., 1922: Macquarie Island and its future. P'ap. Proc. R. Soc. Tasm., 1922:39.54

ROBCRTSON, G., 1986: Population size and breeding suecess of the Gentoo Penguin, Pyposce/is papua, at Macquarie Island. Aust. Wildl. Res., 13: 583587

ROUNSEVELL, D.E.\& COPSON, G.R., 1982: Growth rate and recovery of a King Penguin, Aptenodyesparagonicus, population after exploitation. Aust. Wildl Res., 9: 519-525.

SEPPEIT, R.D., COPSON, G.R. \& BROWN, M.J., 1984: Vascular flora and vegetation of Macquarie island. Tasm. Nat, 78: 7 i3.

SHAUGHNESSY, P.D., SHAUGHNESSY, G.L. \& FLETCHER, L., 1988: Recovery of the fur seal population at Macquarie Island. Pap. Proc. $R$. Soc. Tasm., 122(1): $\mathrm{xx}-\mathrm{xx}$

SKIRA, I.J., 1984: Breeding distribution of the Brown Skua on Macquarie Island. Emu, 84(4): 248-249.

SKIRA, I.J., BROTHERS, N.P. \& COPSON, G.R., 1983: Establishment of the European Rabbit Flea on Macquarie Island. Alsst. Wildl. Res., 10: $121-127$.

TAYLOR, B.W., 1955: The flora, vegetation and soils of Macquarie Island. ANARE Rep., Ser. B(Il), 19.

TAYLOR, R.H. 1979: How the Macquarie Island Parakeet became extinct. N.Z.J. Ecol., 2: 42-45.

TOMKINS, R.J., 1985: Reproduction and mortality of Wandering Albatrosses on Macquarie Island. Emu, 85(1): $40-42$.

(accepted 25 September 1987) 